\title{
The Florentine Quattrocento and the art historiography in Aby Warburg
}

\author{
O Quattrocento florentino e a historiografia da arte em Aby \\ Warburg
}

\section{Serzenando Alves Vieira Neto}

\section{ABSTRACT}

The work of Aby Warburg (1866-1929), which is, above all, dedicated to the great theme of the survival of the classical tradition in the European Renaissance, has gained notoriety in recent decades, including in Brazil. This article seeks to engage in the work of this historian, circumscribing the discussion, in particular, to the thesis on Botticelli and some successive studies on the theme of the Florentine Quattrocento. We present a reading guided by an effort of contextualization, in which we intend to identify Warburg's main historiographical references, demonstrating his latent interlocution with the art historiography produced in the Germanspeaking world. In this sense, this article sustains that Warburg was clearly aligned with the tradition of "art history as cultural history", present in the work of authors such as Jacob Burckhardt, Anton Springer and Hubert Janitschek.

\section{KEYWORDS}

German historiography; Renaissance; Florence.

\section{RESUMO}

A obra de Aby Warburg (1866-1929), dedicada, sobretudo, ao grande tema da sobrevivência da tradição clássica no Renascimento europeu, vem ganhando notoriedade nas últimas décadas, inclusive no Brasil. Neste artigo, propõe-se uma imersão na obra desse historiador, circunscrevendo-se, em especial, à tese sobre Botticelli e a alguns estudos sucessivos sobre o tema do Quattrocento florentino. Apresenta-se uma leitura orientada por um esforço de contextualização no intuito de identificar as principais referências historiográficas e demonstrar a latente interlocução da obra de Warburg com a historiografia da arte produzida no mundo de língua alemã. Nesse sentido, sustenta-se a tese de que Warburg se colocou nitidamente alinhado à tradição de "história da arte como história da cultura", presente na obra de autores como Jacob Burckhardt, Anton Springer e Hubert Janitschek.

\section{PALAVRAS-CHAVE}

Historiografia alemã; Renascimento; Florença. 
Abraham Moritz Warburg (1866-1929) is nowadays a central figure in theoretical-methodological debates, especially in the fields of art history and history of culture. Traditionally known as the founder of a leading historical research institute - since 1944 incorporated to the University of London - he is also the author of significant contributions to the study of receptions and transformations of the classical tradition during the Renaissance period. The magical practices and astrology; the art of portraiture; art and literature in the "early Renaissance" (Frührenaissance) - are examples of themes in which he has been interested throughout his career. It is a known fact that Warburg's methodology of research was based, so to speak, on interdisciplinary principles, which postulated the inseparability between art, philosophy, literature, and religion (SAXL 1970, p. 326). The thematic of the fifteenth-century Renaissance in Florence is more precisely limited to the university years of the young Warburg and his early work. Although this was a topic that accompanied him throughout his career, gradually, over the years, Warburg began to focus on more heterodox themes - astrology and magical practices, for example - and devoted his energies to even larger projects, such as the establishment of a center for historical research in Hamburg.

This article debates precisely that part of Warburg's production which has as its background his university years and his first professional projects. Choosing as object of analysis texts which can be considered strategic within his studies on the theme of the fifteenth-century Florence, this article seeks to relate them with the intellectual tradition from which they emerged, emphasizing Warburg's interlocution with the historiography of art produced in the German-speaking world of his time.

\section{First incursion into the Renaissance}

At the age of twenty, the young Warburg began his university studies. As a student of art history, he attended the 
universities of Bonn, Munich and Strasbourg. Also noteworthy is his period in Florence as a participant of August Schmarsow's project in favor of the foundation of a historical-artistic institute in that city. During his formative years, Warburg took courses with well-established intellectuals, such as Carl Justi (art history), Kekulé von Stradonitz (classical archeology) and Hermann Usener (philology), and with young scholars such as Henry Thode (art history), Karl Lamprecht (history) and Hubert Janitschek (art history), who was also his advisor.

Warburg's thesis $(1893)^{1}$ represents not only an initial approach to the study of Florentine art and culture, but also the draft of a large historical research program. Concretely, his thesis investigated the meaning of the Birth of Venus and Spring based on literary references. Essentially, an iconographic study:

This work sets out to adduce, for purposes of comparison with Sandro Botticelli's celebrated mythological paintings, the Birth of Venus and Spring, the analogous ideas that appear in contemporary art theory and poetic literature, and thus to exemplify what it was about antiquity that "interested" the artists o the Quattrocento (WARBURG 1893, p. 89).

To show how Sandro Botticelli dealt with contemporary views of antiquity, as a force that demanded resistance or submission, and how much of that force became his "secondary substance", has formed the purpose of this inquiry (WARBURG 1893, p. 142).

To summarize, Warburg sustained the idea that Poliziano was the erudite mentor of Sandro Botticelli in the conception of Birth of Venus and Spring. The humanist translated to the painter the classical knowledge, in particular, Ovid and Claudian. The two poets of Antiquity inspired the depiction of "accessories in motion" (bewegtes Beiwerk), observed by Warburg in the flowing garments and hair. Gombrich links Warburg's concept of "accessories in motion" (bewegtes Beiwerk) to the work of Reumont, Lorenzo di Medici (1883) in which Botticelli's manifested predilection for Antiquity and classical accessories (GOMBRICH 1970, p. 58) had already been mentioned.

Warburg, in his attempt to investigate the iconography of
1 - Even though the year of 1893 is usually referred to as the year of publication, specialized literature has shown that, in fact, Warburg's thesis was published by August Osterrieht in Frankfurt in 1892 (RÖSCH 2010, p. 150). 
Botticelli's mythological paintings, sought to answer a personal inquiry that had instigated him for some time. As Gombrich shows in his intellectual biography, Warburg's chief impulse toward art history did not stem from an aesthetic interest, but from problems of ethics and expression arisen from the reading of The Laocoon (1766) (GOMBRICH 1970, p. 23-24; BING 1965, p. 310). The idea that the Quattrocento artists thought and used the legacy of Antiquity as a model, always diverging from naturalism when they had to represent forms in motion (WARBURG 1893, p. 104; WARBURG 1893, p. 108), was, therefore, related to the theoretical background of Lessing's book. For Warburg, Lessing's static conception of the plastic arts does not correspond to the spirit of the "early Renaissance" (Frührenaissance). Antiquity was not seen by the Renaissance man in an idyllic, merely Apollonian fashion. On the contrary, the reception of Antiquity during Renaissance had traces of the tension, typical of a transition moment.

If, on the one hand, the primary intellectual inquiry of Warburg's doctoral research was conceived before his university period, on the other, the methodology he employed to perceive his aims was closely linked to his university training, in particular to the influence of his doctoral advisor, Hubert Janitschek, ${ }^{2}$ and to the influence of "art history as cultural history" from Jacob Burckhardt. The idea that literature offers effective subsidies for the study of the figurative arts has, in effect, defined Warburg's argumentative scheme. Not coincidentally, one of the most cited bibliographical references in the thesis was the book on the history of Italian literature by Adolf Gaspary (GASPARY 1885).

The primacy of literature and cultural phenomena was an idea that pervaded the historiographical production of Warburg's supervisor. Janitschek was a specialist in the literary culture of the Renaissance and made his reputation as the editor of Alberti's writings (JANITSCHEK 1877). In his studies on the society of the Renaissance, Janitschek suggests the precedence of cultural phenomena over artistic transformations. For example, the process of the so-called "discovery of nature"

\begin{abstract}
2 - Janitschek's influence on Warburg's thinking is a marginal question in critical studies. Gombrich briefly comments: "Warburg's choice of another university fell on Strasbourg, where the holder of the chair was Hubert Janitschek, a less distinguished historian of art, surely, than Justi, but one who belonged to the younger generation and who would not be out of sympathy with Warburg's theoretical approach. [...] For Janitschek, too, sociology was a form of social psychology and art was a perfect index of the mentality of a period" (GOMBRICH 1970, p. 54).
\end{abstract}


was first preceded by a change of attitude by the Church - the rehabilitation of nature by Boaventura and Thomas Aquinas. The same happened with the poetic translation that took place in Dante's theological-philosophical teaching. And, finally, the enthusiasm of modern man with nature, symbolized by Petrarch. It was only with the introduction of the above-mentioned cultural elements that a different stance could take place in respect to the plastic arts (JANITSCHEK 1879, p. 35-36).

Jacob Burckhardt had already observed the phenomenon of the preponderance of culture, respectively, of literature, on artistic development. In his masterpiece The Civilization of the Renaissance in Italy (1860), he outlined this process:

Here, as in other things in Italy, culture - to which poetry belongs - precedes the plastic arts and, in fact, gives them their chief impulse. More than a century elapsed before the spiritual element in painting and sculpture attained a power of expression in any way analogous to that of the Divine Comedy. How far the same rule holds good for the artistic development of other nations, and of what importance the whole question may be, does not concern us here. For Italian civilization it is of decisive weight (BURCKHARDT 1860, p. 203).

It can be said that the accurate investigation of the literary sources and the cultural surroundings around the work of art guided a certain art historiography of Warburg's time, specially that one associated with the perception of art as an essentially historical phenomenon (PRANGE 2004, p. 93 et seqq.). Anton Springer, one of the main persons responsible for the methodological and institutional consolidation of art history as a "scientific" discipline in the German academic world, talked about the importance of the historical-contextual approach and the accurate literary knowledge:

[...] the art history should describe the airs, which the artists and their generations breathed; the surroundings, in which they passed; the influences, which they found; the heritage they have managed and sought to increase. We call this, historical delineation, or in a more accurate definition, historical-cultural background. In recent times the art history has undoubtedly been, with great zeal and visible predilection, enriched by the 
historical-cultural approach (SPRINGER 1867, v. 2, p. 399).

The refined knowledge of the history of literature is indispensable to the art historian. The mere confrontation of literary activity and artistic activity of an era, or even a brief preliminary sketch of what a period has achieved in the instances of poetry and literature, is not sufficient for the purposes of art history (SPRINGER 1867, v. 2, p. 402).

Therefore, from a methodological standpoint, Warburg's alignment with a certain art historiography seems quite clear. In addition to this, Warburg's thesis brings, in its background, an essential concern for the nineteenth-century historiography, the role of Antiquity in the constitution of the cultural and artistic life of fifteenth-century Italy.

Henry Thode was one of the leading interpreters of the thesis of the spontaneous stylistic development, ${ }^{3}$ in which a marginal role is given to the influence of Antiquity. The new moment in Italian history - marked by the emergence of a new poetry, a new art and a general freedom of thought - was, in fact, an internal phenomenon. For Thode, the person directly in charge of this movement was Francis of Assisi, maximum representative of a new feeling of individuality and the inaugurator of a new era of the history of humanity (THODE 1885, p. 15).

Jacob Burckhardt ${ }^{4}$ was the chief exponent of a diametrically opposite interpretation. For the Swiss historian, the legacy of Greco-Roman civilization became highly esteemed and influent on Italian life from the fourteenth-century on. It came to be seen as the source and cultural basis, object and ideal of existence. The combination of Antiquity with the genius of the Italian people gave rise to an extremely rich moment in the artistic, cultural and literary spheres. A cultural unit was formed. From Dante's poetry to the beginning of the Counter-Reformation, the Italian specificities, together with the heritage of Antiquity, formed the basis of the Renaissance culture:

The Renaissance would not have been the process of worldwide significance which it is, if its elements could be so easily separated from one another. We must insist upon it, as one of

3 - Carl Justi also supported the thesis of the spontaneous stylistic development (RÖSCH 2010, p. 43).

4 - Georg Voigt's "The revival of classical Antiquity or the first century of humanism" (Die Wiederbelebung des classischen Alterthums oder das erste Jahrhundert des Humanismus) (1859) was another important work to support the bond between the Renaissance man and Antiquity. 
the chief propositions of this book, that it was not the revival of antiquity alone, but its union with the genius of the Italian people, which achieved the conquest of the Western world. [...] The rest of Europe was free either to repel or else partly or wholly to accept the mighty impulse which came forth from Italy (BURCKHARDT 1860, p. 120).

The Middle Ages had knowledge of the Antiquity; in fact, it experienced its own renaissance moments. However, the mere interest in Antiquity was not enough to exhaust the theme. It was necessary that knowledge coincided with the emergence of a new historical context. Italy, with its new social order, was remarkably adequate:

But the great and general enthusiasm of the Italians for classical antiquity did not display itself before the fourteenth century. For this a development of civic life was required, which took place only in Italy, and there not till then. It was needful that noble and burgher should first learn to dwell together on equal terms, and that a social world should arise which felt the want of culture, and had the leisure and the means to obtain it. But culture, as soon as it freed itself from the fantastic bonds of the Middle Ages, could not at once and without help find its way to the understanding of the physical and intellectual world. It needed a guide, and found one in the ancient civilization, with its wealth of truth and knowledge in every spiritual interest. Both the form and the substance of this civilization were adopted with admiring gratitude; it became the chief part of the culture of the age (BURCKHARDT 1860, p. 123).

Anton Springer was another important historian, whose work was known to Warburg, to discuss the role of Antiquity in the Renaissance. Springer conceives Antiquity as indispensable and inseparable from Italian art of the fifteenth and sixteenth centuries (SPRINGER 1867, v. 1, p. 30). In this way, Springer can be seen as a link with Burckhardt's tradition. The uniqueness of the Renaissance can be understood through comparison with other historical contexts:

Rubens has, undoubtedly, a wider knowledge of Antiquity than most of the Renaissance artists. [...] Nevertheless, no one would add Rubens or Poussin to the Renaissance artists. In the Renaissance, Antiquity presented itself as the immediate 
complement of nature. Antiquity served as a mean to contemplate nature in a clearer and purer way. In the imagination of the men of those times, the millennium that separated classical Antiquity from present simply did not exist. For Rubens, and especially for his successors, Antiquity had, in fact, become a time distant in the past, separated from the present by an insurmountable abyss (SPRINGER 1867 , v. 1, p. 244-245).

Concerning the influence of Antiquity in Middle Ages, a continuation in the way of living is observed by Springer. Thus, even in its most critical period, ancient legacy was not completely ignored by the Middle Ages (SPRINGER 1867, v. 1, p. 9). Although, it must be said, Renaissance is defined by a much more intense reception of Antiquity. Springer's interpretation, therefore, is based on the idea of the survival of the classical tradition as a process, so to speak, of long duration, conceptually defined as "survival of Antiquity" (Nachleben der Antike). Later, Warburg incorporated this concept into his work (FORSTER 1999, p. 6; GOMBRICH 1970, p. 49; LEVINE 2013, p. 52).

In a conference in 1901, we can see the maturation of Warburg's conception of the influence of Antiquity, a problem that appears as a latent question in his doctoral thesis, which is here presented in a more explicit and cohesive manner:

Our great difficulty in treating the artistic culture of the early Renaissance is to understand the naturalness of its relationship with antiquity. For the men and artists of the early Florentine Renaissance, antiquity did not present itself as being plastered, in "simplicity and grandeur of style" [...]. Antiquity was for the Florentine Etruscans an image - unique, passionate, moving, and partially forgotten - of their own life, which suddenly became vividly and unevenly colored, at a time when the gravity of the situation evoked nostalgia in any direction in which the Platonic idea - detached from the temporal corporeality - could dance in the wheel of eternity (WARBURG 1901b, p. 225). 


\section{Subsequent topics: the art of portraiture, Flemish art, the Renaissance man}

The thesis on Botticelli's mythological paintings was successful. It was praised by Herman Grimm. The professor of art history in Berlin asserts that Warburg's thesis gives the impression of being part of a greater project, a very interesting one, which proposes to demonstrate the connection of the Florentine Quattrocento with the classical art and literature. For Grimm, such project should be carried out in later studies (GRIMM 1893, p. 690). The thesis was also praised by the septuagenarian historian, Jacob Burckhardt. The Swiss shows his admiration specially for the fact that Warburg was successful in rebuilding the social, poetic, and humanistic milieu in which Sandro lived and painted (KAEGI 1933, p. 285). So, after some "setbacks" (military service, medical studies, travel to America), Warburg retook his research, beginning the most fruitful period of his production on the theme of the Florentine Quattrocento. As stated above, this theme is present throughout his entire intellectual trajectory, including his late years (1924-1929). In 1914 , for example, Warburg gave a lecture on the beginning of the "antiquating" style in the "first Renaissance" (Frührenaissance) (WARBURG 1914). Even in his seminary at the University of Hamburg (1928) Warburg worked on themes related to his youth period: the Renaissance in the fifteenth-century; Florence and the Medici; the relationship between bankers and the promotion of culture (DROMMERT 1995, p. 14). However, the period between 1896 and 1907 deserves special attention for two reasons: firstly, because it was a period marked by long and repeated stays in Florence, where Warburg resided between 1897 and 1904, visiting its archives and libraries assiduously; secondly, because, at that time, Warburg was fully engaged in the project of gaining academic space. For this reason, focusing on a theme that was well-established and potentially promising was a more consistent strategy ${ }^{5}$.

This period of about ten years resulted in several studies on the theme of the fifteenth-century Florence. Among these

5 - On the challenges of Warburg's early career and his attempt to write his "habilitation" (Habilitationsschrift), see especially: (DIERS 1991, p. 146 et seqq. SLOVIN 1995, p. 63 et seqq.) 
studies, there are two texts on the art of portraiture, published in 1902, which are noteworthy and were the result of Warburg's research in the archives of Florence. Also important is an essay on Francesco Sassetti (1907), which presents a more mature interpretation of the society and the man of the Renaissance.

The art of portraiture and the Florentine bourgeoisie (1902) is a central study in the context of Warburg's production. In this work, as in his thesis, he turned his attention to the Medicis. A very fruitful research object, since it gives a clear understanding of two phenomena - the intimate relationship between patron and artist; and the patron's desire to be eternalized in the artistic representation. In this study, Warburg focused his attention on the fresco The confirmation of the Franciscan rule in the basilica of Santa Trinita, in which he identified the following characters: Francesco Sassetti; Lorenzo de Medici; the children of Lorenzo, Piero, Giovanni and Giuliano; Angelo Poliziano; Matteo Franco; Luigi Pulci.

Warburg's study had its merits. The relevance of his research and, hence, its importance to understand the art of Ghirlandaio and the society that produced it, is undeniably acknowledged (CADOGAN 2000, p. 8). In spite of this, a closer look at the historiography of the time reveals the limits of Warburg's achievements, in particular, the lack of originality. Warburg writes in a letter about his effort to identify some personalities in Ghirlandaio's fresco by studying genealogies, ancient chronicles and fiscal records (GOMBRICH 1970, p. 129). However, most of the relationships established by him derive from a secondary source, Heyck's book on the Medici (HEYCK 1897, p. 65-66, 70, 99-100, 112-114).

Even though Warburg's essay lacks originality, it was extremely significant for drawing attention to a theme that was beginning to gain prominence at the turn of the century, the art of portraiture. Once again, Warburg transits between art history and cultural history, a necessary movement, since, as he states: "In a living art of portraiture, the motive forces of evolution do not reside solely in the artist" (WARBURG 1902b, p. 187). The 
transition from a devotional context to a secularized one, in which a donator wishes to express his power, was an issue that had already been signaled by the nineteenth-century historiography, as the following excerpt from Janitschek's book on the Renaissance society shows:

The Middle Ages were impelled into art through devotional necessity; in the Renaissance period, the same need played a very small role. The donator's devotional intent was no longer of any value, but the work itself should proclaim to the posterity the greatness and power of its financier (JANITSCHEK 1879, p. 75).

However, the theme of the art of portrait received in-depth attention with Burckhardt's posthumous book Contributions to the history of Italian art (Beiträge zur Geschichte der Kunst von Italien) (1898). In this investigation, Burckhardt focused on three themes: the portraiture, the altar painting, and the collectors. While in his masterpiece, The Civilization of the Renaissance in Italy (1860), Burckhardt did not address the place of art in Renaissance society, in Contributions to the history of Italian art (1898), he sought to fill this gap. It represented, in the general context of Burckhardt's legacy, the conclusion of the project of embracing art and culture with the effective approximation of the world of artists based on a conception of art according to "themes and tasks" and "the means and capacities" (FERNANDES 2012, p. 29).

In The art of portraiture and the Florentine bourgeoisie (1902), Warburg acknowledges the pioneering spirit of Jacob Burckhardt. For Warburg, Burckhardt expanded the investigative possibilities, effectively opening up the perspective of researching Renaissance art through the problem of the genres and functions. Instead of presenting an interpretation based on a closed unit, Burckhardt dissected the culture of the Renaissance though superficially disjointed parts. In Cicerone (1855), he demonstrated his deep knowledge of the Italian art works - a passionate young scholar with accurate vision and memory, travelling through the cities of his beloved Italy. In The civilization of the Renaissance in Italy (1860) he sought the "psychology of the individual in society" (WARBURG 
$1902 \mathrm{~b}, \mathrm{p} .186)$. In this context, Burckhardt's posthumous book presents itself as an attempt to balance the concrete artistic elements with the great historical-cultural panorama of the Renaissance, a path which would be followed by Warburg:

He [Burckhardt] opened up yet a third empirical path to the great objective of a synthesis of cultural history. He undertook the labor of examining the individual work of art within the immediate context of its time, in order to interpret as "causal factors" the ideological and practical demands of real life. Our perception of the greatness of Jacob Burckhardt must not deter us from following in his footsteps (WARBURG 1902b, p. 186).

Burckhardt's book was not only a significant reference for the understanding of Florentine Renaissance society, but also served to draw Warburg's attention to a fundamental historical phenomenon in the understanding of the art of portraiture - the exchanges between Flemish and Italian art and culture. In this respect, in 1901, Warburg asserts: "The theme of the influence of Flemish art in Italy was first broached by that pioneering model, Jacob Burckhardt, who assembled the detail and described the evolutionary process in broad terms" (WARBURG 1901a, p. 305). Warburg was interested in Flemish culture, mainly, in the identification of the people and donors ${ }^{6}$ represented and in the study of inventories and commercial contracts.

When tracing the context of the evolution of the art of portraiture, Burckhardt called the attention for this matter in broad outlines. For the Swiss historian, from Giotto onwards, Italian painting was based on a new will and a new capacity, the artist's self-portrait alongside with the representation of illustrious contemporaries. The altar retables showed this trend (even in the North):

It was precisely from this model that Italian painting opened the doors to the portrait. The kneeling figures of the donors were placed in the foreground, or among the saints, in the altar retables, and this was also the case in the North. Although only Italy possessed a great religious, historical and allegorical public painting on the walls and ceilings in the durable form of the fresco, which was monumental in its conception and execution (BURCKHARDT 1898, p. 151).
6 - Warburg was motivated, above all, by the new photographic resources, which made possible the comparative analysis of the pictures, consequently, the unprecedented deepening in the art of portraiture (WARBURG 1901a, p. 305). 
In Flemish art and the Florentine early Renaissance (1902), Warburg shows that the fifteenth-century patrons were captivated by the illusionism and verisimilitude of people, animals and landscapes - as represented by the artists of the North. The arazzo - Flemish or French tapestries depicting the heroic deeds of biblical or classical Antiquity, or of the age of the medieval knights - was a very coveted and expensive object. This made the Italians try to attract Flemish weavers to cities like Milan, Mantua, Ferrara, Florence, Siena, and Rome (WARBURG 1902a, p. 281). The appreciation for the Flemish realism and the new conception of the individual were characteristic elements of this context, which Warburg aimed to reconstruct, thus, revealing new artistic patterns and behavior.

Warburg's article highlighted, more specifically, the exchange between Florence and Bruges. For Warburg, the contact between such opposing nationalities enabled the art of portraiture to evolve surprisingly. In Bruges, an absolutely unique work was produced, the "result of the encounter between a merchant venturer from Lucca and a Northern painter" (WARBURG 1902a, p. 282). The portrait of the couple Arnolfini represented the intimacy of the home by the painter Jan van Eyck, a work of nature that "stands beyond beauty and ugliness" (WARBURG 1902a, p. 283).

For Warburg, the exchange between Bruges and Florence is a historical phenomenon that constitutes the Renaissance:

The specific quality of the paintings sent home by the Medici representatives in Bruges inevitably influenced Italian painting toward a sense of depth for just so long as the general evolution of art demanded - and also tolerated - keener attention and sharper observation of detail: until, in fact, the Italian "eagles" dared to take wing and soar to the higher world of ideal forms (WARBURG 1902a, p. 298).

The cosmopolitan aspect of the Renaissance alludes to the link between Warburg and other Jewish historians of the turn of the century. This generation was attentive to the political developments of modern Germany and tried hard to find historical 
models that could elucidate Germany's present and indicate alternatives. ${ }^{7}$ Alfred Doren, for example, pointed out that the civilizational achievements of the Renaissance were marked by national aspects, but did not imply delimitations in relation to other cultures. This author gave prominence to the figure of the Italian merchant, a kind of "global citizen" (Weltbürger), the expression of a cosmopolitan era (LADWIG 2004, p. 59-60). For a whole generation, the study of the exchanges between European "nationalities" during the Renaissance was not merely a scholarly exercise, but a way to promote the development of a tolerant and cosmopolitan cultural model.

The last great historical-cultural issue investigated by Warburg in his studies of the fifteenth-century Florence was the "psychology of the Renaissance man". This problem began to be traced in Flemish art and the Florentine early Renaissance (1902). In this study, Warburg showed how the typically medieval ecclesiastical posture was exhausted, even though men of the period continued to nourish a deep devotional feeling. The Florentines that are represented in Memling's Last Judgment exemplify the modern attitude alongside with the evocation of the archangel's protection:

The Flemish style, with its deft blend of inner spirituality and outer truth to life, was the ideal vehicle for the donor portrait. The individuals portrayed were beginning to detach themselves, as individuals, from their ecclesiastical background, not as rebels but simply by natural growth: for "man and the world still blossomed, grafted on a single stem". The hands maintain the self-forgetful gesture of appealing for heavenly protection; but the gaze is directed, whether in reverie or in watchfulness, into the earthly distance. There are overtones, as it were, of the worldly personality; and the lineaments of the self-assured observer emerge, spontaneously, from the posture of the worshiper at prayer (WARBURG 1902a, p. 297).

But, in fact, the problem of the "psychology of the Renaissance man" was deeply analyzed by Warburg in his essay on Sassetti. In this study he investigated Sassetti's last wishes, a document dated 1488, which had already been briefly analyzed by him in 1901 (WARBURG 1901b, p. 211).

\begin{abstract}
7 - In this context, the Renaissance can be seen as a golden age in the development of the ideals of tolerance, something very significant for a Jew of the Wilhelmine Germany: "The culture of the Renaissance is thus living proof that intellectual formation and emancipation are intertwined, and therefore can be seen as an ideal model for the emancipation of German Jews in the nineteenth century" (LADWIG 2004, p. 83).
\end{abstract}


About the document, Warburg writes: "This document contains evidence that can be useful to the art historian if we first make the effort to understand Francesco's thinking to cast light on the psychology of an educated layman in early Renaissance Florence" (WARBURG 1907, p. 223).

The interest in Francesco Sassetti is based on the oscillating aspects of his personality. Francesco was in a delicate historical and existential moment, since he was moving between two different worlds. If, on the one hand, his last injunctions reveal "a man who has a firm and principled attachment to his medieval roots", on the other, they also reveal Francesco's secular mentality, which is expressed through the concern with his assets (WARBURG 1907, p. 233). In sum, this dilemma shows the complex process of the transition to modernity:

For all the down-to-earth, practical tenor of this document, Francesco's own words do not instantly reveal him as a man of the new age. On the contrary, the Middle Ages - if by that we mean an old-fashioned and backward-looking attitude, as opposed to that of the egocentric superman in quasi-antique disguise - seems not only to persist in the habitual religious sentiments of his vita contemplativa but to determine the style of his vita activa (WARBURG 1907, p. 239).

In this, the most critical moment of his life, which demands the concentration of all his energies, Francesco finds himself summoning up, together, the two antithetical forces that mold his determination to survive: in him, the instinctive valor of the Ghibelline chieftain, rooted in the ideals of chivalric caste and family feeling that maintained the medieval consorteria, is backed by the conscious daring of humanist-educated individualism. The knight, rallying his clan to make a last stand around the family banner, receives from the Florentine Renaissance merchant, as a device for that banner, the windblown goddess Fortune, who presents herself so vividly to him as the personification of fate (WARBURG 1907, p. 240).

Sassetti's sarcophagus caught Warburg's attention: how was it possible for a devout Christian to allow savage heathen spirits around his tomb? "How did Sassetti attempt to reconcile the pagan histrionics of the sarcophagus with a traditional, medieval view of the world?" (WARBURG 1907, p. 247). The 
answer to this question - a characteristically Renaissance dilemma - can be found, according to Warburg, in the Adoration of the Shepherds of Ghirlandaio. A sacred theme that absorbs Antiquity through architecture (WARBURG 1907, p. 247-249):

In all good Faith, Francesco Sassetti could thus display his Christian piety amid the signs and portents of the Roman world; not because he was at all capable of kneeling in guileless prayer, like one of the shepherds, oblivious of the alien stonework all around, but because he believed that he had laid the unquiet spirits of antiquity to rest by building them into the solid conceptual architecture of medieval Christianity. He was not to guess - before the advent of Savonarola - just how critical a test this optimistic attempt to absorb and enlist antiquity would prove to be (WARBURG 1907, p. 249).

The Renaissance was seen by Warburg as a period of transition, characterized by a conflict between the "Dionysian drunkenness" (dionysisch) and the "Apollonian lucidity" (apollinisch) (DIDI-HUBERMAN 2002, p. 133). Even though the period was dominated by internal strife, there is no doubt that the search for a conciliatory posture moved the Renaissance men - as the case of Francesco Sassetti shows.

In this context, Warburgs talks about a certain "polarity psychology" (Polaritätspsychologie), ${ }^{8}$ which makes clear his distance from Burckhardt's Renaissance ideal, especially in two of his most characteristic features: paganism ${ }^{9}$ and individualism.

Burckhardt's interpretation of the Renaissance individual identifies a change of posture, the so-called "objective treatment of reality". In one of the most well-known passages of The Civilization of the Renaissance in Italy (1860), we can read:

In the Middle Ages both sides of human consciousness - that which was turned within as that which was turned without lay dreaming or half awake beneath a common veil. The veil was woven of faith, illusion and childish prepossession, through which the world and history were seen clad in strange hues. Man was conscious of himself only as a member of a race, people, party, family or corporation - only through some general category. In Italy this veil first meted into air; an objective treatment and
8 - Warburg defined his text on Sassetti as an essay onthe "psychology of polarity" (Polaritätspsychologie) (LADWIG; TREML; WEIGEL 2010, p. 193). This is a topic that has permeated all his production. In a 1926 conference, Warburg identifies this "polar tension" in ancient culture. As he claims, the historians of religion and the psychologists have long demonstrated that the demonic - the experience preserved in the most unpleasant expression - is part of the antique culture (WARBURG 1926, p. 177).

9 - On the question of paganism, Warburg can be situated in an intermediate position between the eminently Christian conception defended by his professor Thode and Burckhardt's characteristically pagan interpretation. 
consideration of the state and of all the things of this world became possible. The subjective side at the same time asserted itself with corresponding emphasis; man became a spiritual individual, and recognized himself as such (BURCKHARDT 1860, p. 98).

For Burckhardt, the impulse to the highest individual development in conjunction with a spirit capable of assimilating all elements of culture at the same time brought to life the figure of the uomo universal. This "all-sided man" was characteristic of the Renaissance and belonged to Italy alone (BURCKHARDT 1860, p. 101). The other face of the Renaissance man and the process of the highest individual development was the so-called "modern glory". Restricted to Italy, it meant the genesis of a society in which all social classes are equal. In this context, a homogeneous society emerged having as its support the Italian and Latin literature (BURCKHARDT 1860, p. 104). Italy was an example of society in which the illustrious men were profoundly respected and venerated. In general, these were individuals that attempted to discover the world, to revolutionize and inaugurate a golden period in the history of civilization (as opposed to the dark period of the Middle Ages).

In a letter to Warburg (1907), Alfred Doren praised the study on Francesco Sassetti (LADWIG 2004, p. 111). For Doren, the Renaissance was also a period of transition, in which opposite tendencies were assimilated. The typical man of the Renaissance was immersed in the tension between two worlds. With the advance of historical research - including here Warburg's - the ideal of the Renaissance man, as propagated by Burckhardt, seemed to have lost its validity. According to Doren: "We know today [1922/23] that the Renaissance man, as interpreted by Burckhardt, was a conscious stylistic construct, typically idealistic" (LADWIG 2004, p. 111).

For Fritz Saxl, the essay on Sassetti represents a true "point of transition" (Wendepunkt) of Warburg's work. It coincides 


\section{Final considerations}

with a shift towards not merely historical studies, but true documents for humanity (MCEWAN 2004, 24). Thus, it can be said that, from 1907 on, Warburg starts a new phase of his career, marked by the gradual shifting of his interest to the question of the influence of astrology and the East (Iranianplateau) on the Renaissance. ${ }^{10}$ It should be noted that Warburg's historical production on the theme of fifteenth-century Florence is part of a larger picture. His studies on Dürer, on the frescoes of the Palazzo Schifanoia, on the role played by the figure of the Nymph during Renaissance, on the festive activities - all comprise fundamental elements of his historical and theoretical picture of the Renaissance. Nevertheless, the texts dealt with in this article allow a general understanding of his research specifically focused on issues regarding the Florentine society and art, in which dilemmas characteristic of his work appear in a latent dialogue with the art historiography of his time. In addition, such texts can be seen as the most relevant material that Warburg published during his life on the theme of the Florentine Quattrocento.

When searching for the references underlying Warburg's research, it was not the intent of this article to produce an exhaustive and comprehensive presentation. For that, it would be necessary to consider at least another important dimension of his thought, his theoretical-philosophical foundations. An in-depth understanding of his dialogue with the scientific, aesthetic and psychological literature of the late nineteenthcentury, especially with authors such as Karl Lamprecht, August Schmarsow, Robert Vischer, Friedrich T. Vischer, Charles Darwin, Tito Vignoli, Hermann Usener. With this in mind, this article focused on the main historiographical and methodological issues and references, which appear, directly and indirectly, in Warburg's research on the Florentine Quattrocento. Thus, the main objective here was to evidence his interlocution with a certain historiography of German language, which was 
concerned, above all, with the sociocultural aspects around art; mainly, with historians such as Anton Springer, Hubert Janitschek and Jacob Burckhardt. Therefore, this study presents the grounds to sustain the thesis that it was precisely on the basis of these intellectual references that Aby Warburg developed his historical research on fifteenth-century Florence.

\section{REFERENCES}

BING, Gertrud. A. M. Warburg. Journal of the Warburg and Courtauld Institutes, v. 28, p. 299-313, 1965.

BURCKHARDT, Jacob. Beiträge zur Kunstgeschichte von Italien: das Altarbild, das Porträt in der Malerei, die Sammler. Basel: C. F. Lendorff, 1898.

\section{The civilization of the Renaissance in}

Italy. London: Penguin, 2004 [1860].

CADOGAN, Jean K. Domenico Ghirlandaio: artist and artisan. New Haven, London: Yale University, 2000.

DIDI-HUBERMAN, Georg. A imagem sobrevivente: história da arte e tempo dos fantasmas segundo Aby Warburg. Rio de Janeiro: Contraponto, 2013 [2002].

DIERS, Michael. Warburg aus Briefen: Kommentare zu den Kopierbüchern der Jahre 1905-1918. Weinheim: Acta Humaniora, 1991.

DROMMERT, René. Aby Warburg und die Kulturwissenschaftliche Bibliothek in der Heilwigstraße. In: GALITZ, Robert; REIMERS, Brita (Orgs.). Aby Warburg: »Ekstatische Nymphe... trauernder Flußgott« Portrait eines Gelehrten. Hamburg: Dölling und Galitz, 1995, p. 14-18.

FERNANDES, Cássio. O lugar de o retrato na pintura italiana do Renascimento na obra de Jacob Burckhardt. 
In: BURCKHARDT, Jacob. O retrato na pintura italiana do Renascimento. Campinas, São Paulo: Unicamp, FapUnifesp, 2012, p. 21-47.

FORSTER, Kurt. Introduction. In: WARBURG, Aby. The renewal of pagan Antiquity: contributions to the cultural history of the European Renaissance. Los Angeles: Getty Research Institute, 1999, p. 1-75.

GASPARY, Adolf. Geschichte der italienischen Literatur. Strassburg: K. J. Trübner, 1885.

GRIMM, Herman. Sandro Botticelli, Geburt der Venus und Frühling. Deutsche Literaturzeitung, v. 14, p. 690-692, 1893.

GOMBRICH, E. H. Aby Warburg: an intellectual biography. $2^{\mathrm{a}}$ ed. Chicago: The University of Chicago, 1986 [1970].

HEYCK, Eduard. Die Mediceer. Bielefeld, Leipzig: Velhagen \& Klasing, 1897.

JANITSCHEK, Hubert. Die Gesellschaft der Renaissance in Italien und die Kunst: vier Vorträge. Stuttgart: W. Spemann, 1879.

.L.B.Alberti'skleinerekunsttheoretische

Schriften. Wien: W. Braumüller, 1877.

KAEGI, Werner. Das Werk Aby Warburgs: mit einem unveröffentlichten Brief Jacob Burckhardts. Neue Schweizer Rundschau, v. 1, n. 5, p. 283-293, 1933.

LADWIG, Perdita. Das Renaissancebild deutscher Historiker 1898-1933. Frankfurt am Main: Campus, 2004.

LADWIG, Perdita; TREML, Martin; WEIGEL, Sigrid. Die Nymphe und pagane Totenklage: Die Renaissance als Übergangszeitalter. Vorbemerkung der Herausgeber. In: Aby Warburg: Werke in einem Band. Berlin: Suhrkamp, 
2010, p. 187-197.

LEVINE, Emily J. Dreamland of humanists: Warburg, Cassirer, Panofsky, and the Hamburg School. Chicago, London: The University of Chicago, 2013.

MCEWAN, Dorothea. Wanderstrassen der Kultur: die Aby Warburg - Fritz Saxl Korrespondenz 1920 bis 1929. Hamburg, München: Dölling und Galitz, 2004.

PRANGE, Regine. Die Geburt der Kunstgeschichte: Philosophische Ästhetik und empirische Wissenschaft. Köln: Deubner, 2004.

ROECK, Bernd. Der junge Aby Warburg. München: C. H. Beck, 1997.

RÖSCH, Perdita. Aby Warburg. Paderborn: Wilhelm Fink, 2010.

SAXL, Fritz. The history of Warburg's library (1886-1944). In: GOMBRICH, E. H. Aby Warburg: an intellectual biography. $2^{\mathrm{a}}$ ed. Chicago: The University of Chicago, 1986 , p. 325-338 [1970].

SLOVIN, Francesca Cernia. Obsessed by art - Aby Warburg: his life and his legacy. [S.I.]: Xlibris, 2006 [1995].

SPRINGER, Anton. Bilder aus der neueren Kunstgeschichte. Bonn: Adolph Marcus, 1886 [1867]. 2 vol.

THODE, Henry. Franz von Assisi und die Anfänge der Kunst der Renaissance in Italien. Essen: Emil Vollmer, 1998 [1885].

WARBURG, Aby. Conferencia sobre Rembrandt. In: WARBURG, Aby. Atlas Mnemosyne. Madrid: Akal, 2010 [1926], p. 173-178. 
in die Malerei der Frührenaissance. In: WARBURG, Aby. Werke in einem Band. Berlin: Suhrkamp, 2010 [1914], p. 281-310.

. Flemish and Florentine art in Lorenzo de' Medici's circle around 1480. In: WARBURG, Aby. The renewal of pagan antiquity: contributions to the cultural history of the European Renaissance. Los Angeles: Getty Research Institute, 1999 [1901a], p. 305-307.

Flemish art and the Florentine early Renaissance. In: WARBURG, Aby. The renewal of pagan antiquity: contributions to the cultural history of the European Renaissance. Los Angeles: Getty Research Institute, 1999 [1902a], p. 281-303.

. Florentinische Wirklichkeit und antikisirender Idealismus. In: WARBURG, Aby. Werke in einem Band. Berlin: Suhrkamp, 2010 [1901b], p. 211-233.

- Francesco Sassetti's last injunctions to his sons. In: WARBURG, Aby. The renewal of pagan antiquity: contributions to the cultural history of the European Renaissance. Los Angeles: Getty Research Institute, 1999 [1907], p. 223-262.

Sandro Botticelli's Birth of Venus and Spring.

In: WARBURG, Aby. The renewal of pagan antiquity: contributions to the cultural history of the European Renaissance. Los Angeles: Getty Research Institute, 1999 [1893], p. 89-156.

. The art of portraiture and the Florentine bourgeoisie. In: WARBURG, Aby. The renewal of pagan antiquity: contributions to the cultural history of the European Renaissance. Los Angeles: Getty Research Institute, 1999 [1902b], p. 185-221.

. Vom Arsenal zum Laboratorium. In: WARBURG, Aby. Werke in einem Band. Berlin: Suhrkamp, 
2010 [1927], p. 683-694.

AGRADECIMENTOS E INFORMAÇŌES

\section{Serzenando Alves Vieira Neto}

savieiraneto@yahoo.com.br

Doutorando em história da arte pelo PPG-História

Universidade Estadual de Campinas

RECENED IN: 23/10/2017 | APPROVED IN: 17/04/2018 